\section{A Reforma de Lutero: uma releitura ecumênica*}

\author{
Elias Wolff**
}

RECIBIDO: 23-07-16. APROBADO: 12-10-16

Resumo: A Reforma de Lutero configurou novos modos de ser cristão e ser Igreja com implicaçóes para todo o cristianismo. Isso requer uma hermenêutica ecumênica da Reforma, o que aqui se faz analisando as relaçôes entre as igrejas católica e luterana. O objetivo é compreender o que da Reforma pode ser hoje recebido pelas duas tradições eclesiais, na especificidade de cada uma. Os resultados apresentam católicos e luteranos como coherdeiros da Reforma de Lutero naquilo que mantém a Igreja fiel à sua origem, Cristo, partilhando a fé comum e testemunhando o Evangelho no mundo.

Palavras Chave: Reforma, Lutero, justificação, Igreja, ecumenismo.

PARA CITAR ESTE ARTÍCULO:

Wolff, Elia "A reforma de lutero uma releitura ecumênica”. Theologica Xaveriana 183 (2017): 209-235. https://doi.org/10.11144/javeriana.tx67183.rlrepr

\section{La Reforma de Lutero: uma relectura ecuménica}

La Reforma de Lutero configuró nuevos modos de ser cristiano y de ser Iglesia con implicaciones para toda la cristiandad. Como consecuencia, se requiere de una hermenêutica ecuménica de la Reforma, la cual se propone aquí a través del análisis de las relaciones entre las iglesias Católica y Luterana. El objetivo es comprender que la Reforma puede ser recibida hoy por las dos tradiciones eclesiales desde la especificidad de cada una de ellas. Los resultados presentan a los católicos y a los luteranos como coherederos de la Reforma de Lutero en aquello que mantiene a la Iglesia fiel a su origen -Cristo-, compartiendo la fe común y testimoniando el Evangelio en el mundo.

Palabras clave: Reforma, Lutero, justificación, Iglesia, ecumenismo.

\section{Luther's Reformation: An Ecumenical Rereading}

Luther's Reformation set up new ways of being Church and of being Christian with implications to Christianity as a whole. Therefore, an ecumenical hermeneutics of Reformation is required, which is practiced here by analyzing the relations between the Catholic and the Lutheran churches, in order to comprehend those aspects of Reformation that may be received nowadays by these two ecclesial traditions according to each one's specificity. The results show Catholics and Lutherans as coheirs of Luther's Reformation in what keeps each Church faithful to its origin, Christ, by which they share a common faith and give testimony of the Gospel to the world.

Key Words: Reformation, Luther, Justification, Church, Ecumenism.

\footnotetext{
* Artigo, de revisão

** Doutor em Teologia pela Pontifícia Universidade Gregoriana, Roma; Especialista em ecumenismo e diálogo inter-religioso. Atualmente é coordenador da Comissão Teológica do Conselho Nacional de Igrejas Cristãs do Brasil, coordenador do Núcleo Ecumênico e Inter-religioso da PucPr. Orcid: 00000003-2479-2340. Correio eletrônico: elias.wolff@pucpr.br
} 


\section{Introdução}

Às vésperas do quinto centenário da Reforma de Martinho Lutero e seus seguidores no século XVI, é importante fazer uma releitura dos fatos ocorridos, suas motivaçóes e desdobramentos na história, atualizando o seu significado no atual contexto marcado por três principais fatores: a realidade sócio-cultural globalizada, a realidade religiosa plural e o diálogo ecumênico realizado nos últimos 50 anos. Esses elementos possibilitam reler hoje a Reforma aprofundando as suas razões históricas no passado, o que as mantém no presente, e o seu significado para o futuro do cristianismo.

Várias questôes orientam esta reflexão: foi a Reforma expressão de algo negativo na Igreja, ou um fato positivo como fidelidade ao Evangelho? Foi ela um desvirtuamento da vontade de Cristo para a Igreja, ou realização dessa vontade e, portanto, um acontecimento salvífico? As divisóes que ocorreram a partir da Reforma indicam o fim da unidade da Igreja ou, antes, o início de outras formas legítimas de ser Igreja? Essas divisóes são definitivas ou apenas "evidência de uma falha temporária da Igreja” "? Enfim, buscando o significado atual da Reforma é preciso perguntar, também, qual é o nível da ruptura e do vínculo que permanece entre as igrejas protestantes e a tradição católica romana.

Ciente de que a resposta a essas questóes não se darão num só fôlego, não pretendemos tratar aqui de todos os temas relativos à Reforma ou da própria Reforma no seu conjunto. A nossa releitura da Reforma concentra-se na relação entre as tradiçóes católica e luterana. Essa delimitação tem duas principais razóes: conduz à fonte primeira da Reforma, o pensamento de Martinho Lutero; e, considerando que a Reforma não é uma realidade unívoca, a delimitação favorece a objetividade do estudo que realizamos. Esperamos explicitar elementos da Reforma que podem ser acolhidos por todos em nosso tempo, como também os elementos que exigem a continuidade do diálogo que visa estabelecer consensos na fé entre as igrejas católica e luterana.

\section{A complexidade semântica do conceito "Reforma"}

As diferentes igrejas compreendem de modos diversos o que foi a Reforma no passado e qual é o seu significado para o presente. Também os reformadores tinham motivaçóes, métodos e objetivos próprios para o processo reformatório. Lembremos que o processo da Reforma do século XVI é um movimento muito amplo, que inclui diferentes propostas além daquela de Lutero, como as de Felipe Melancton, João Calvino, Ulrico Zuinglio, Tomas Muntzer, Enrique VIII, e movimentos como o

\footnotetext{
${ }^{1}$ Feige, "Thèses catholiques pour la commémoration de la Réforme en 2017. Un défi salutaire", 6.
} 
anabatismo e o pietismo. Em outro estudo, apresentamos diferentes compreensóes do conceito "reforma", entre outras: tentativas de "retorno a um passado idealizado", ou "retorno à Igreja primitiva dos Atos dos Apóstolos", ou uma simples "restauração da disciplina" 2 . Seja como for, são conceitos chaves para entender a Reforma do século XVI os verbos "refazer", "restaurar", "reparar", "reconstruir", no sentido de "fazer de novo" o arcabouço teológico da fé cristã de modo a possibilitar um redimensionamento estrutural da Igreja.

As motivaçóes da Reforma devem-se à compreensão de que algo na Igreja de entâo era inaceitável e precisava ser urgentemente abandonado. Tal é o que Lutero via na teologia escolástica, na prática pastoral e na estrutura eclesiástica centrada no Papa. A prática das indulgências foi vista como uma manifestação concentrada de todos os erros da Igreja. Urgia reformar a Igreja para recuperar o seu centro: a fé no solus Cristhos que justifica. Como esse intento em muito se distanciava do que propunha a Igreja estabelecida, surgem tensóes e conflitos entre a fé católica e a fé protestante que se prolongam até os dias de hoje. De um lado, entende-se que a Reforma condiz com a condição original da verdade cristá, corrigindo desvios na Igreja. De outro lado, a Igreja romana entende-se como única autoridade para afirmar o que está ou não em conformidade com a fé.

O fato é que a expressão "Reforma” não é unívoca. Alguns a entendem de forma positiva, como uma conditio sine qua nom para a verdade da Igreja; outros a vêem como uma ameaça à Igreja. Para alguns, a Reforma é confirmaçâo da identidade confessional; para outros, ela é uma crítica a essa identidade. Há estudos sobre a Reforma que conservam estereótipos, preconceitos e posturas conflituosas a partir dos interesses atuais de quem a lê; mas há também quem lê a Reforma numa perspectiva ecumênica, superando a apologética polêmica. Essa perspectiva leva a entender a Reforma, 500 anos depois, por um lado com uma atitude de alegre celebraçáo; de outro lado, com uma apreciação crítica e reflexiva. Assim, católicos e luteranos entendem que

$\mathrm{Na}$ atualidade, nós somos capazes de redizer juntos a história da Reforma luterana. Mesmo que luteranos e católicos tenham pontos de vista diferentes, pelo diálogo ecumênico eles são capazes de superar as hermenêuticas tradicionais anti-protestantes e anti-católicas, visando encontrar uma maneira comum de fazer memória dos acontecimentos passados. ${ }^{3}$

\footnotetext{
${ }^{2}$ Wolff, "Reformas na Igreja: chegou a vez do catolicismo? Uma aproximação dos 50 anos do Vaticano II e os 500 anos da reforma luterana, no contexto do pontificado do papa Francisco", 537.

${ }^{3}$ Comissão Internacional Católica-Luterana, Do conflito à comunhão: comemoração conjunta católicoluterana da Reforma em 201735, 25.
} 


\section{Dimensões da Reforma}

A pluralidade de significados da Reforma deve-se a muitos fatores, como a diversidade de objetivos, métodos, sujeitos, mediaçóes e contextos. Contudo, dois horizontes lhe são centrais, o sociológico e o teológico.

\section{A Reforma como um fato social}

A Reforma tem implicaçóes políticas, econômicas e culturais que incidem fortemente na formação das sociedades européias dos séculos XVI a XVIII. No pensamento de Lutero, teologia e política se vinculam, como mostram os textos "À nobreza cristã da nação alemâ" (1520), "Da autoridade secular, até que ponto se lhe deve obediência" (1523), "Sobre a liberdade de um cristão" (1520). Para Lutero, não é à jurisdição do Papa que se deve obediência, mas às ordenaçóes sociais divinamente sancionadas, como a família, a Igreja e o Estado que, juntamente com a economia, são os estamentos determinantes do regime temporal. Lutero quer, com isso, desclericalizar a sociedade medieval. Estudiosos identificam aqui um horizonte ideorreligioso na Reforma: a teologização da configuraçâo social e política, como uma justificação teológica do Estado e da sua missão frente à sociedadét. Lutero desenvolve, assim, uma "teologia do mundo" que vincula lei e Evangelho, com uma ética sócio-política que tem a sua hermenêutica e a sua justificaçáo teológica na doutrina dos dois reinos 5 .

A implicação sócio-política apareceu logo. Na Dieta de Espira (1526), foi definido que cada província do império viveria, governaria e obedeceria como pensa melhor responder diante de Deus e de sua majestade imperial. Isso levou a significativas mudanças não apenas no regime eclesial, mas também no sistema judiciário, na economia e na cultura, rompendo de vez com o regime sócio-religioso medieval. Com a doutrina do sacerdócio universal, os leigos assumiram um papel relevante na organização da Igreja.

O pensamento dos dois principais reformadores do século XVI deu uma nova configuração à sociedade moderna. Lutero possibilitou um "luteranismo político como inflexão do luteranismo histórico, o qual desembocou na sançáo teológica do nacionalsocialismo"'. Calvino criou um sistema de crenças com uma ética que seculariza a sociedade e uma racionalização da economia pela ascese e renúncia puritana ao consumo. Para Weber, o espírito religioso da sociedade capitalista é, de um lado,

\footnotetext{
${ }^{4}$ Montes, Reforma luterana y tradicion catolica, 58-60.

${ }^{5}$ Bayer, A teologia de Martim Lutero, 106.

${ }^{6}$ Montes, Reforma luterana y tradicion catolica, 55.
} 
a ética profissional de Lutero; e, de outro lado, a ascese puritana de Calvino7. Não se trata de acordo pleno com essa leitura, mas é inegável a incidência da Reforma nas sociedades européias que a acolheram.

\section{A Reforma como um fato teológico}

As motivaçóes de Lutero para a Reforma foram, substancialmente, de ordem religiosa, originando um movimento de matriz e princípio fundamentalmente teológico que visa reformular a fé cristã com base na doutrina da justificação. Para isso, Lutero questiona três elementos na Igreja do seu tempo: (1) O pensamento teológico centrado na racionalidade da escolástica: "Uma reforma na Igreja é impossível se não se arrancam até a raiz os cânones, os decretais, a teologia escolástica, a filosofia, a lógica... peço a cada dia ao Senhor que uma coisa semelhante aconteça e que se voltem ao estudo puríssimo da Bíblia e dos santos padres”; (2) a prática pastoral, centrada nas devoçóes, nos sacramentos e nas obras - a prática das indulgências é o foco do momento; (3) $o$ papado, como instância definitiva da verdade sobre a fé. Para Lutero esses três elementos desvirtuavam a Igreja do seu centro cristológico, de onde provém a justificação do pecador.

No centro do debate teológico está a soteriologia que interroga: como pode o ser humano ser salvo por Deus? Como ser agradável coram Deo (frente a Deus)? Com que meio Deus salva? Que participação tem o ser humano na sua salvação? A Igreja tem algum papel relevante no processo da justificação do pecador? Lutero não encontra resposta em teologias, doutrinas ou práticas de boas obras, mas numa experiência pessoal do significado da iustia Dei: não é apenas a justiça que Deus nos dá por misericórdia, mas é Cristo que justifica. Entende que "o justo vive pela fé" $(\mathrm{Rm} 1,17)$ e ora a Deus: "pela tua justiça, liberta-me" (S1 31,2). Disso Congar conclui que o princípio reformador para Lutero não está apenas em ter encontrado o significado da justiça divina, mas de tê-lo aplicado ad personam (a mim)'.

Daqui Lutero desenvolve os pilares da sua reforma teológica: sola scriptura como critério decisivo para compreender a justificação do pecador, pois a fé que justifica vem da escuta da Palavra; solus Christus como manifestação plena do poder que Deus tem para justificar; e sola fides para acolher a ação da graça de Deus em Cristo. O princípio

\footnotetext{
${ }^{7}$ Weber, $A$ ética protestante e o espirito do capitalismo.

${ }^{8}$ Lutero, Carta a Jodocus Trutfetter (09/05/1518), in Congar, Lutero. La fede, la Riforma, 40; ver também: Lutero, "Debate sobre a teologia escolástica" I, 13-20.

${ }^{9}$ Congar, Lutero, 30.
} 
"sola scriptura propóe uma regra hermenêutica para um conhecimento adequado e claro do solus Christus, bem como da sola gratia e da sola fide" ${ }^{10}$.

Esses princípios teológicos têm conseqüências eclesiológicas. Fundamentando a doutrina da justificação por graça e fé somente, eles fazem dessa doutrina o articulus stantis et cadentis ecclesiae. A justificação é o fundamento da Igreja como assembléia dos salvos em Cristo. Entra em discussão aqui o ministério ordenado, que para Lutero parecia se contrapor ao sacerdócio universal dos fiéis, à singularidade do sacerdócio de Cristo e à soberania da graça. As açôes ministeriais da Igreja não fundam a justificação, embora a expressem se ocorrem em virtude da fé. A reforma teológica conduz à reforma eclesiológica. Lutero entendia desvencilhar a i Igreja do que considerava obstáculos e desvios no caminho da perfeição, ajudando na recuperação da sua autenticidade como Igreja de Cristo.

\section{Releitura da Reforma em perspectiva ecumênica}

A Reforma de Lutero sustenta novas formas de vida cristã e eclesial, com fundamentação teológica e espiritual em muito divergente das demais igrejas, de onde resultam tensóes e conflitos entre elas. Felizmente, o diálogo teológico entre católicos e luteranos nos últimos 50 anos tem explicitado consideráveis sintonias, convergências e consensos ${ }^{11}$. Isso possibilita hoje uma releitura da Reforma na qual "os teólogos ecumênicos se decidiram a não se ater às suas próprias afirmaçóes confessionais em detrimento de seus parceiros do diálogo, mas, antes, de pesquisar aquilo que eles tem em comum no seio de suas diferenças, ver seus conflitos, para assim avançar na possibilidade de superar as diferenças que separam" ${ }^{12}$. Vejamos como essa postura se manifesta em uma nova compreensão da pessoa de Martinho Lutero, dos princípios sola fide e sola gratia, das obras do justificado e da Igreja.

\section{Nova compreensão de Lutero}

Por séculos, os cristãos católicos tiveram de Lutero a imagem negativa que dele foi construída por Johannes Cochlaeus, cônego de Wittenberg (Comentários sobre as açóes e os escritos de Lutero, 1549), alimentada ainda no século XX por teólogos como o dominicano Henri Denifle (1904) e o jesuíta Hartmann Grisar (em artigos publicados entre 1911/1912). Esses mostraram Lutero como uma pessoa orgulhosa,

\footnotetext{
${ }^{10}$ Grupo de Estudos Ecumênicos de Teológos Protestantes e Católicos, "Réformation 1517-2017: perspectives oecuméniques", 74.

${ }^{11}$ Wolff, "Divisōes na Igreja: desafios para o ecumenismo hoje”, 396-398.

${ }^{12}$ Comissão Internacional Católica-Luterana, Do conflito à comunhão 17.
} 
emocionalmente desequilibrada, um pervertido moral e envolvido em angústias sem fim, o que o tornava psicologicamente e espiritualmente doentio, cheio de escrúpulos e ansiedades, atormentado pelo temor do pecado e do demônio.

Tal visão de Lutero é hoje superada nos meios acadêmicos sérios, pois "negar a Lutero todo tipo de justiça histórica não presta um serviço nem à Igreja e nem à verdade [...] não se faz honra ao catolicismo que se mostre lealdade a ele insultando e injuriando Lutero" ${ }^{13}$. Estudiosos católicos de Lutero entendem que "a evolução psicológica do jovem religioso e as suas angústias não nasceram de uma perversão moral" ${ }^{14}$. Sua motivação fundante era a busca do Deus da graça e, no contexto de uma cristandade marcada por todo tipo de abuso, "Lutero combateu um catolicismo que não era católico"15.

Os católicos reconhecem hoje em Lutero a sua riqueza espiritual, os seus talentos, o seu zelo pelas novas comunidades e a sua atenção à graça de Deus revelada em Cristo ${ }^{16}$. O Reformador foi um religioso fervoroso, com profunda experiência de Deus e "se esforçou para anunciar o Deus vivo revelado em Jesus Cristo, o Deus bíblico e não o Deus de uma metafísica" ${ }^{17}$; tinha um profundo sentido do pecado e das fragilidades humanas, mas autêntica e inabalável confiança na graça de Cristo. Assim, não se pode dizer que tudo em Lutero era oposição à fé da Igreja do seu tempo.

Não se trata de ver apenas santidade em Lutero, há riquezas e contrariedades no seu temperamento, onde se misturam "Autêntica e profunda religiosidade, tendência ao subjetivismo, ao autoritarismo e à violência, eis alguns traços essenciais do reformador" ${ }^{18}$. O seu temperamento forte e descomedido nem sempre facilitava o consenso em questôes disputadas. Não são, contudo, os elementos possivelmente negativos do temperamento do Reformador que devem determinar a compreensão da sua pessoa e da sua proposta reformatória.

Sem negar tensóes e conflitos por ele causados e sem precisar aceitar a totalidade de sua doutrina, pode-se reconhecer o que Lutero contribuiu para a compreensão da fé cristã, como uma "Testemunha do Evangelho, um mestre da fé e um mensageiro

${ }_{13}$ Wicks, Lutero e il suo patrimonio spirituale, 17. Dentre os principais estudos de católicos sobre Lutero na atualidade, destacam-se: Iserloh, "Come i cattolici giudicano Lutero oggi", 16-27; Lortz, La Réforme de Luther; Staufer, Le catholicisme à la découverte de Luther; idem, "Mutamenti della interpretazione cattolica della figura di Lutero e loro limiti"; Lienhard L'Evangile et l'Eglise chez Luther.

${ }^{14}$ Martia, História da Igreja: de Lutero a nossos dias. I: O periodo da Reforma, 121.

${ }^{15}$ Lortz, The Reformation in Germany.

${ }^{16}$ Wicks, Lutero e il suo patrimonio spirituale, 18.

17 Lienhard, "Luther, notre maitre comum"?, 259.

${ }^{18}$ Martia, História da Igreja, I, 123. 
de renovação espiritual" ${ }^{19}$. A causa do Evangelho estava na raiz do seu intento de reformas na Igreja: "Quando criticava os diversos aspectos da tradiçâo teológica e da vida da Igreja do seu tempo, Lutero se considerava uma testemunha do Evangelho, um “indigno evangelista de nosso senhor Jesus Cristo" ${ }^{20}$. Assim, teólogos católicos não exitam em afirmar que Lutero "permaneceu firme na profissão de fé na Igreja Católica (WA 50, No. 624; 51, No. 479), criticando o papa de abandonar a catholica em favor da 'romana' e assim fez da Igreja uma seita (WA 7, No. 753; 50, No. 626)" ${ }^{21}$.

Reconhecendo que a motivação de Lutero por reformas na Igreja era a fé em Cristo, conclui-se que a razão dos questionamentos que ele fez à Igreja foi, igualmente, a fé. Lutero não pretendia desvirtuar a Igreja da fé verdadeira, dividir a Igreja ou criar outra Igreja. Ele buscava uma fé pura, sem mediaçôes excessivas, fundamentada na Bíblia e nos padres para além do racionalismo teológico e o engessamento doutrinal; uma organização eclesial centrada na experiência da fé em Cristo e não na disciplina institucional.

A conseqüência seria uma Igreja mais dinâmica e comunional, de comum dignidade entre os batizados; a vida cristã centrada na pessoa de Cristo revelado nas Escrituras e presente a nós na encarnação e na Cruz; a fé em Cristo e na soberania divina orientada pela Palavra; e uma liturgia que torna o mistério celebrado acessível aos simples. Eis o núcleo da Reforma de Lutero, que pode ser acolhido por cristãos católicos. Afinal, "os apelos de Lutero para a reforma da Igreja, isto é, à penitência, são ainda válidos para nós. Ele nos exorta a escutar de novo o Evangelho, a reconhecer a nossa infidelidade ao Evangelho e a testemunhá-lo de uma forma credível”22.

\section{Sola fide, sola gratia}

Esses princípios luteranos foram entendidos como oposição aos meios da salvaçáo, tais quais os sacramentos, a prática das boas obras, a própria Igreja. De fato, Lutero afirmou que a salvação é recebida unicamente por fé, criticando mediaçóes valorizadas pela Igreja. Mas essas críticas se dão num contexto de vivência da fé com forte risco de pelagianismo, como o racionalismo escolástico, o abuso da prática das indulgências, o modo como a hierarquia eclesiástica vivia.

Em que medida os questionamentos a tais realidades significavam negação das mediaçóes da salvação? Lutero tem consciência de que a fé se obtém da Palavra

\footnotetext{
${ }^{19}$ Comissão Internacional Católica-Luterana, "Martin Lutero, Testimone di Gesù Cristo" 4 (744).

${ }^{20}$ Ibid. 7 (744).

${ }^{21}$ Kasper, A Igreja Católica: essência, realidade, missão, 232, Nota 140.

${ }^{22}$ Comissão Internacional Católica-Luterana, "Martin Lutero, Testimone di Gesù Cristo" 6 (744).
} 
e unicamente nela se funda. Mas a Palavra exige meios para ser acolhida, como o ministério da pregação por ele mesmo entendido como uma instituição da Igreja e concretização da vontade divina. Dessa forma, não se pode facilmente concluir que em Lutero o sola fides se opóe às mediaçóes da fé que justifica. O Reformador não quer negar a visibilidade da graça, mas encontra-se num dilema entre a afirmação institucional da ação salvífica da graça e a ameaça que essa apresenta para à soberania da graça.

É importante compreender o que Lutero entende por fé. Trata-se de uma experiência particular e endereçada à Palavra e à pessoa de Cristo, como fidúcia absoluta, acreditando na eficácia daquilo que anuncia ou promete. É algo concreto e existencial, pois a promessa diz respeito à pessoa do crente. Isso implica uma visão da salvação e da revelação onde se encontra aquilo que Deus é pro me, quando "recebemos e permitimos a um outro operar em nós, a saber, Deus" ${ }^{23}$. Não é a fé em si mesma que justifica, mas a fé como obra de Deus, na qual ele exerce a sua soberania. Assim, a justificação pela fé não faz da fé o princípio causal da justificação, não suplanta a soberania divina e sua graça manifestada em Cristo.

\section{As obras do justificado}

O Reformador afirma que só a fé salva, mas não nega as obras como conseqüências da ação divina, testemunhas e frutos da fé que justifica. $\mathrm{O}$ justificado realiza obras que revelam a justiça de Deus nele; são obras de justiça, que emanam da nova realidade na qual o justo vive. Essa "nova realidade" mostra que a ação da graça não é sem efeito na vida do crente.

A leitura ecumênica dos artigos VI e XX da Confissão de Augsburgo (CA) mostra que a justificação gratuita por Cristo não exclui as obras do processo de justificação, simplesmente afirma que elas não podem causar a justificação, como mérito humano. O contexto da CA é a intenção anti-pelagiana de Lutero e seus companheiros, sobretudo Melanchton, opondo-se à doutrina escolástica do mérito. Está em questão como a CA apresenta a doutrina da justificação, questionada pela teologia católica em seu aspecto imputativo. Estudos ecumênicos mostram que a CA não afirma uma "compreensão forense e unilateral" da justificação ${ }^{24}$, mas algo efetivo, que além de perdoar os pecados também torna a pessoa de fato justa, regenera. Lutero temia a identificação que a escolástica tardia fazia entre gratia gratum faciens e caritas, bem

\footnotetext{
${ }^{23}$ Lutero, "Comentário da Epístola aos Gálatas”, 10, 30.

${ }^{24}$ Meyer, "La confessio Augustana, en quanto confesión católico-luterana, es un camino para la unión de los cristianos"? Citado: Montes, Reforma luterana y tradicion catolica, 209.
} 
como a concepção semi-pelagiana do habitus (que capacita o ser humano para o bem por si mesmo).

O diálogo atual entre católicos e luteranos estabeleceu consensos nessa questão $0^{25}$. Afirma que "a justiça de Deus e a justificação do homem estão em relação íntima" ${ }^{26}$; que "a questão sobre se a pessoa é declarada justa ou é realmente feita justa é uma falsa alternativa" ${ }^{27}$. O simul iustus et peccatur mostra que o perdão dos pecados e a presença santificadora de Deus é simultânea. Os católicos entendem a exclusividade da fé como "causalidade instrumental" da justificação; e os luteranos afirmam que "o ato da justificaçâo não está limitado ao perdão individual dos pecados: não vêem nele uma declaração puramente exterior da justiça do pecador" ${ }^{28}$. A justificação por fé afirma que a sua única causa é solus Christus - pressuposto de sola fides - um acontecimento salvífico total ${ }^{29}$. Tal é o principal consenso teológico atual:

É somente pela graça por meio da fé na ação salvífica de Jesus Cristo, e não com base aos nossos méritos, que somos aceitos por Deus e recebemos o Espírito Santo que renova os nossos coraçóes, nos habilita e nos chama a realizar boas obras $^{30}$.

Assim, toda justiça vem de Deus e se obtém pela fé, também essa um dom de Deus, em contraposição à justiça própria, da lei (Rm 1,17; 3,5.21-31; Fl 3,9; Gl 5,4). Mas as obras são os bons frutos da fé. A expressão luterana mere passive não compreende a fé como simples aceitação de verdades, "passividade" não é apatia, e "sola gratia se relaciona à necessidade de uma fé atuante" ${ }_{31}$. "Cooperação" não significa iniciativa própria, e "mérito" qualifica as obras sem anular a iniciativa divina ou afirmar a conquista humana da salvação. Manifestam a presença de Deus na pessoa justificada, pelo que as obras expressam crescimento na graça e responsabiliza a pessoa pelos

\footnotetext{
${ }^{25}$ Comissão Internacional Católica-Luterana, vem afrontando a questão há muito tempo, particularmente nos documentos O Evangelho e a Igreja (1972), Igreja e justificação (1994); o diálogo católicoluterano nos EUA: Justificação pela fé (1983); e o trabalho do grupo de teólogos católicos e evangélicos da Alemanha: Condenaçóes doutrinais. Divisoras da Igreja? (1986). Em 1995, a Comissão Internacional encaminhou às igrejas o texto que deveria ser examinado pelas instâncias eclesiásticas competentes, o que resultou na Declaração comum sobre a doutrina da justificação por graça e fé (1999).

${ }^{26}$ Lorscheider, "Declaração conjunta da Federação Luterana Mundial e da Igreja Católica Romana sobre a doutrina da justificação", 25.

${ }^{27}$ Brakemeier, "Doutrina da justificação. No limiar de um acordo ecumênico?” 36.

${ }^{28}$ Comissão Internacional Católica-Luterana, "Il Vangelo e la Chiesa” 26 (565).

${ }^{29}$ Ibid. 27 (565).

${ }^{30}$ Federação Luterana Mundial e Pontifício Conselho para a Promoção da Unidade dos Cristãos, Declaração conjunta sobre a doutrina da justificaçāo por graça e fé 15.

${ }^{31}$ Brakemeir, "Doutrina da justificação", 35.
} 
seus atos. Existe, enfim, "uma concepção dinâmica da justificação onde a graça não despersonaliza o ser humano, que sempre de novo é chamado a responder à palavra e ao agir de Deus como pessoa viva" ${ }^{32}$.

Com isso, a doutrina da justificação não mais separa hoje católicos e luteranos, mesmo se nela existe ainda um "consenso diferenciado", no sentido que o conteúdo dessa doutrina é comum, mas permite linguagens e desdobramentos próprios em cada igreja, sem contradizer o que as igrejas crêem juntas ${ }^{33}$.

\section{A Igreja}

O fato de Lutero desenvolver a doutrina da justificaçáo no horizonte da soteriologia cristocêntrica o faz construir uma eclesiologia distinta da vigente no seu tempo. A Igreja é uma instância da proclamação do Evangelho e está, portanto, relacionada à fé em Cristo que justifica. Lutero busca afirmar a todo custo a "Igreja do Evangelho", entendendo retornar, assim, à antiga tradição.

Para o Reformador, a Palavra faz a Igreja: "A Igreja nasceu da Palavra da promessa pela fé [...] A Palavra de Deus é incomparavelmente acima da Igreja, e sua função não é estabelecer, ordenar ou criar o que é (mas) ser estabelecida, ordenada e criada enquanto criatura" ${ }^{34}$. E os congregados pela Palavra formam a Igreja como populus fidelis (Dictata super Psalterium) e congregatio sanctorum. Para além de uma estrutura eclesiástica, a Igreja é "uma congregação de todas as pessoas na terra que crêem em Cristo" ${ }^{35}$. Mas qual é a sua forma histórica? No contexto da polêmica Lutero afirmou que essa Igreja é contrária à "Igreja do Papa", sustentada em leis e instituiçóes humanas. A Igreja não consiste em elementos visíveis, pois é formada interiormente pelo Espírito Santo. Mas ela exterioriza-se no batismo, na ceia e no Evangelho: "Os sinais pelos quais é possível ver exteriormente onde se encontra no mundo esta Igreja, são o batismo, o sacramento do altar e o Evangelho [...] Lá onde existam o batismo e o Evangelho, ninguém poderá duvidar que existam santos" ${ }^{36}$.

Ao afirmar a Igreja como reuniāo dos fieis que acolhem a Palavra, Lutero não nega a realidade objetiva da igreja como instância da graça. Pois a fé, resposta à Palavra, não é a fé do indivíduo particular, mas a fé da Igreja que proclama a Palavra e também

\footnotetext{
32 Federação Luterana Mundial e Pontifício Conselho para a Promoção da Unidade dos Cristãos, "Parecer", 51.

${ }^{33}$ Idem, Declaração conjunta sobre a doutrina da justificação por graça e fé 5 .

${ }^{34}$ Lutero, "Do cativeiro babilônico da Igreja" 2, 410-411.

${ }^{35}$ Idem, "A respeito do Papado em Roma contra o celebérrimo romanista de Leipzig" 2, 208.

${ }^{36}$ Ibid., 216.
} 
normatiza os seus conteúdos ${ }^{37}$. A partir da Palavra tem-se uma compreensão da unidade da Igreja: "a escuta comunitária da palavra de Deus e o apego fiel ao único Evangelho (cf. Gl 1,6-10) são passos indispensáveis na via da unidade plena” ${ }^{38}$. Assim, a Igreja tem uma função definida no processo da justificação.

O que Lutero pretende é buscar a Igreja das origens. Não se trata de reproduzir a forma histórica da Igreja apostólica, mas o seu significado. Ele entende que mudanças na organização, na prática e nas estruturas são açôes externas à Igreja, necessárias para assegurar a sua verdade interior: a fundação em Cristo, de quem recebe autoridade e vitalidade para pregar o Evangelho e administrar os sacramentos, expressóes maiores da fé. Lutero busca "mais Cristo e menos Igreja" ${ }^{39}$. Assim, a Reforma sustenta sua identidade confessional priorizando a Bíblia em relação aos elementos institucionais. Relativiza a mediação eclesiástica da graça, o ministério ordenado. Exceto o batismo e a ceia, os sinais da fé são destituídos de valor sacramental. O art. VII da $C A$ coloca em segundo plano os elementos exteriores da Igreja, como a organização administrativa e a disciplina. Isso levou muitos a entenderem que Lutero negou completamente o valor da Igreja e seu papel na salvaçáo que Deus oferece à humanidade.

Hoje entende-se que havia diferentes compreensóes da relação entre a Igreja e a justificação, mas “para Lutero a Igreja é, por vontade de Cristo, referência objetiva da mediação da graça divina, em virtude da Palavra e do Sacramento que nela existem" ${ }^{\text {" }}$. O Reformador não nega o valor dos ministérios e dos sacramentos na Igreja, e sim a forma como eram vividos no seu tempo. Ele entende que o ministério "se embasa na vontade e instituição divina. Mesmo se o sacerdócio é comum a todos os crentes, os ministros ou pastores se distinguem em realidade, dos outros membros da Igreja pela missão de pregar que lhes é dada por Deus" ${ }^{41}$.

E nos sacramentos Lutero acentua a iniciativa da generosidade divina sobre a ação meritória de quem os recebe: "os dons autênticos de Deus são transmitidos através do Evangelho e os sacramentos de Cristo" «2. Logo, "Onde, pois, a Palavra e os sacramentos permanecem substancialmente, ali está a santa Igreja” ${ }^{43}$. O diálogo atual reitera: "A Igreja é a comunidade de todos que Deus reúne por Cristo no Espírito

\footnotetext{
${ }^{37}$ Montes, Reforma luterana y tradicion catolica, 92.

${ }^{38}$ Comissáo Internacional Católica-Luterana, "Vie verso la comunione" 15 (661).

${ }^{39}$ Congar, Lutero, 73.

${ }^{40}$ Montes, Reforma luterana y tradicion catolica, 24.

${ }^{41}$ Wicks, Lutero e il suo patrimonio spirituale, 21.

${ }^{42}$ Ibid., 22.

${ }^{43}$ Lutero, "Comentário da Espístola aos Galatas", 47.
} 
Santo através do anúncio do Evangelho e a distribuição dos sacramentos e o ministério por ele instituído para tal fim" ${ }^{44}$.

Há diferentes compreensóes da Igreja e da sua concretização histórica, cada uma delas reivindicando legitimidade e autenticidade da Igreja una, santa, católica e apostólica. Mas, em estado de divisão, pode uma Igreja afirmar-se como privilegiada ou superior manifestação da Igreja una? O Vaticano II afirma que na Igreja Católica existe uma fiel e plena realização da Igreja de Cristo ( $L G 8)$, mas admite a eclesialidade das demais ( $U R$ 3; $L G 15)$ e humildemente reconhece que as divisóes "impedem a Igreja de realizar a plenitude de catolicidade que lhe é própria [...] torna-se mais difícil exprimir sob todos os aspectos a plenitude da catolicidade na realidade da vida" (UR 4). A conclusão é que "a catolicidade pode, em prática, se realizar somente numa comunhão ecumênica" ${ }^{45}$.

Isso torna imperativo uma eclesiologia ecumênica para os dias de hoje, elaborada tanto por elementos da Reforma, quanto da Igreja anterior e posterior ao processo reformatório, convergindo diferentes perspectivas eclesiológicas. Esforços para isso são conhecidos ${ }^{46}$. Não se trata apenas de uma nova leitura da Reforma, mas sim afirmar que a aspiração por reformas é uma "necessidade perene" (UR6) da Igreja. As reformas permitem compreender que "A origem da Igreja é a manifestação de Cristo, realizada de novo em cada circunstância, em continuidade com a Igreja primitiva, e cuja presença é manifestada a pessoas específicas ao mesmo tempo na palavra e nos sacramentos" ${ }^{\prime 7}$. Urge o consenso nos atributos essenciais da Igreja: unidade, santidade, catolicidade e apostolicidade. Para isso é importante rever o significado atual da Reforma, o que "não se trata de contar uma história diferente, mas de contar de uma maneira diferente" o acontecido ${ }^{48}$, reconhecendo as suas contribuiçóes para a realização histórica da Igreja de Cristo.

\section{Uma ruptura com singular continuidade da catolicidade}

$\mathrm{Na}$ medida em que se aprofunda o estudo sobre a Reforma e seus desdobramentos, inevitavelmente ela é relacionada com a tradição católica e surgem questôes como: o que na Reforma significa ruptura com a Igreja de então? O que há de continuidade?

\footnotetext{
${ }^{44}$ Comissão Internacional Católica-Luterana, “Tutti sotto uno stesso Cristo” 16, 698.

${ }^{45}$ Grupo de Estudos Ecumênicos de Teólogos Protestantes e Católicos, "Réformation 1517-2017”, 80.

${ }^{46}$ Dentre outros: Cereti, Per un'eclesiologia ecumenica; Tavard, A Igreja, comunidade de salvação: uma eclesiologia ecumênica; Wolff, A unidade da Igreja. Ensaio de eclesiologia ecumênica.

${ }^{47}$ Grupo de Estudos Ecumênicos de Teólogos Protestantes e Católicos, "Réformation 1517-2017”, 69.

${ }^{48}$ Comissão Internacional Católica-Luterana, Do conflito à comunhão 16 (18).
} 
Pode ser a Reforma também uma contribuição com a tradição católica? Com a Reforma a unidade com a Igreja de Roma foi perdida, seja pelas doutrinas reformatórias, seja "pelas circunstâncias dramáticas acompanhadas pelos anátemas recíprocos” ${ }^{49}$. Mas a ruptura não foi total, as novas comunidades cristâs mantiveram elementos da tradição da fé comum. Vejamos como isso se manifesta.

\section{A consciência da necessidade de reformas}

As duras críticas que Lutero fez à Igreja expressavam a sua compreensão de que um projeto de reforma radical se fazia necessário e que era seu dever promovê-la "Comentário aos Romanos" ${ }^{\circ}$. Ele entende que "A Igreja tem necessidade de uma reforma; o que não é tarefa de uma única pessoa, do pontífice, nem de muitos cardeais como provou, a ambas as coisas, o último concílio - mas de todo o mundo, mais ainda: unicamente de Deus" ${ }^{11}$. E conclui: “...é impossível dar luz às Escrituras e reformar as outras igrejas, se não se reforma logo aquela 'universal real', a cúria romana”"52. Lutero endurece em suas assertivas:

Visto que o Papa juntamente com os seus simplesmente se nega a realizar um concílio, não querendo reformar a Igreja nem acrescentar qualquer progresso ou remediar, e sim querendo que a Igreja vá à ruína... nada podemos fazer, e temos que [...] buscar conselho e ajuda em outra parte e, antes de tudo, buscar e pedir uma reforma junto a nosso senhor Jesus Cristo. ${ }^{53}$

Desde então, o caminho para reformas na Igreja implicava em distanciamento da Igreja instituída. A ruptura seria inevitável, o que estudiosos entendem ter acontecido a partir de $1520^{54}$, com o escrito "Do cativeiro babilônico da Igreja" (1520) $)^{55}$. A essa altura, os textos de Lutero apresentam os elementos do que se pode hoje chamar de um "programa" de reforma, destacando: (1) Em "À nobreza cristã da nação alemã (1520)" transfere aos leigos a autoridade da Igreja; (2) em "Resposta ao livro de Ambrosio Catarino (1521)" ${ }^{57}$, critica a vida do clero, a cúria papal, as devoçóes, a missa sem fiéis,

\footnotetext{
${ }^{49}$ Ibid., 68.

${ }^{50}$ Lutero, "A epístola do bem-aventurado apóstolo Paulo aos Romanos" 8, 254-330.

${ }^{51}$ Idem, "Explicações do debate sobre o valor das indulgências. Tese 89" 1, 188.

${ }^{52}$ Congar, Lutero: “Comentário aos Gálatas (1519)”, 56, Nota 123.

${ }^{53}$ Lutero, "Dos concílios e da Igreja” 3, 306.

${ }^{54}$ Congar, Lutero, 61.

${ }^{55}$ Lutero, "Do cativeiro babilônico da Igreja"2, 341-424.

${ }^{56}$ Idem, "À nobreza cristã da nação alemã, acerca da melhoria do estamento cristáo" 2, 277-340.

${ }^{57} \mathrm{Idem}$, "Resposta de Martinho Lutero ao livro de nosso exímio mestre mag. Ambrósio Catarino, acérrimo defensor de Silvestre Priérias com a explicação da visão de Daniel Cap. 8: sobre o antricristo” 3, 11 -95.
} 
a rejeição do cálice aos leigos, o celibato, a supremacia do direito canônico em relação à teologia, etc.; (3) em "Do cativeiro babilônico da Igreja", Lutero propóe questóes mais dogmáticas, como os três sacramentos (batismo, ceia e penitência) que precisam, porém, ser libertados da doutrina e do poder do papa; nega serem sacramentos outros sinais da fé; afirma que cada cristão é sacerdote, eliminando a distinção clero-leigos.

\section{Sem querer abandonar a Igreja}

Não obstante o acima considerado, é surpreendente observar que em diversas passagens de seus escritos Lutero se afirma dentro da Igreja, tal como seus companheiros, ele não quer dela sair e muito menos dividi-la: "os reformadores não desejavam fundar uma nova Igreja, e, segundo sua própria compreensão, eles não o fizeram. Eles queriam reformar a Igreja [...] embora com erros e equívocos" ${ }^{58}$. Até 1520 afirmava respeito e obediência à autoridade eclesial, como mostra o envio das 95 teses aos bispos, e na carta sobre o encontro que deverá ter com Caetano, em 1518, diz que cabe à Igreja julgar seus posicionamentos ${ }^{59}$. Mesmo depois da excomunhão (1520), “até 1522, Lutero se dirige aos bispos como pode fazê-lo um católico" ${ }^{60}$. E refere-se com orgulho ao fato de ter recebido das altas instâncias da Igreja a missão de ensinar as Escrituras.

Inclusive depois das duras polêmicas, após 1520, Lutero entendia que não estava abolindo tudo na Igreja romana:

Nós reconhecemos que, sob o papado, existem muitas coisas cristâs boas, isto é todo o bem cristão. E também, que isto nos vem de lá. Especificamente reconhecemos que no papado existe a Santa Escritura autêntica, o autêntico batismo, o autêntico sacramento do altar, as autênticas chaves para o perdão dos pecados, a autêntica função da pregação, o autêntico Catecismo, como o Pai Nosso e os dez mandamentos, os artigos da fé [...], o autêntico cristianismo. Esta mesma santa Igreja é o lugar sagrado da abominação. Pois Deus, com o seu poder e através de um milagre, cuidou daquilo que permaneceu sob o Papa... Lá onde semelhantes elementos permaneceram, estão seguramente seja a Igreja ou alguns santos. ${ }^{61}$

Assim, existe em Lutero significativa expressão de catolicidade, o que muito se deve à sua formaçáo com o uso de Agostinho, Bernardo, Boaventura, os místicos da Idade Média, seu amigo Staupitz. Ele reconhece na Igreja os meios da graça que provém de Cristo, e exatamente por isso não se propóe criar uma nova Igreja:

\footnotetext{
${ }^{58}$ Comissão Internacional Católica-Luterana, Do conflito à comunhão 222, 83.

${ }^{59}$ Congar, Lutero, 51.

${ }^{60}$ Ibid., 51.

${ }^{61}$ Ibid.: Lutero, "Von der Winkelmesse und Pfaffenwihe", 67.
} 
E nós mesmos, que suportamos os fardos e os erros da cúria romana, talvez por isto fugiremos e nos separaremos? Absit, absit. Nós criticamos, nós detestamos, nós pregamos, nós advertimos, mas náo nos separaremos [...] sabendo que a caridade está acima de tudo. ${ }^{62}$

O que Lutero quer é "reformar", isto é, purificar e restaurar a ordem eclesial conforme o Evangelho. Diz à Igreja: "Não queremos anular seu Evangelho, nem pregar outro. Queremos apenas purificá-lo e poli-lo como a um espelho obscurecido e estragado" ${ }^{3}$.

Contudo, seja por desenvolvimentos do pensamento e de emoçóes próprias, seja pelo contexto polêmico das discussóes acaloradas, Lutero não tinha todas as condições de apreciar positivamente a Igreja de então. A conseqüência foi o desequilíbrio entre Escritura e tradição, comunidade eclesial e ministros, fé e sacramento, direito e teologia/ espiritualidade, Papa e concílio.

\section{Ospírito católico de Lutero}

Mas a Reforma não pretendia ser um prejuízo à tradição católica, como mostra o "espírito católico" de Lutero, para além dos estereótipos doutrinais que enclausuram a profissão de fé. "Lutero está mais presente do que se pensa, na teologia atual", inclusive católica ${ }^{64}$. Esse "espírito católico" do Reformador não é um simples acordo espiritual com a doutrina do Papa, mas a conservação de elementos da fé cristá comuns a diferentes tradiçóes, oriundos da catolicidade da fé da Igreja antes indivisa. A Reforma de Lutero conservou importantes elementos da fé da Igreja antiga. "Lutero foi penetrado pelas tradiçóes medievais e influenciado pelos movimentos de reforma católica, o mistiticismo da Idade Média tardia e a teologia da vida religiosa" ${ }^{\circ}$.

Ao combater as obras como meios para a justificação, Lutero entendia ajudar a Igreja a combater o pelagianismo, sustentava-se em Agostinho e confrontava a teologia de Biel: "Por isso não queremos dizer nem acreditamos ter dito qualquer coisa que não esteja de acordo com a Igreja católica e os mestres da Igreja" ${ }^{66}$. Ele mantém os símbolos antigos da fé cristã - apostólico, niceno-constantinopolitano e atanasiano - entendendose fiel à Igreja apostólica e oposto à Igreja medieval por estar distanciada da origem em Cristo e ter perdido a pureza e a integridade evangélica. Lutero afirma, reiteradas vezes,

\footnotetext{
${ }^{62}$ Lutero, "Comentário aos Gálatas (1519)”, 81.

${ }^{63}$ Idem, "Prédicas semanais sobre Mateus 5-7" 9, 83.

${ }^{64}$ Pesch, “O estado atual do entendimento", 125.

${ }^{65}$ Feige, “Thèses catholiques pour la commémoration de la Réforme en 2017”, 8.

${ }^{66}$ Lutero, "Debate sobre a teologia escolástica", 20.
} 
a necessidade de resgatar as Escrituras e os Padres como únicos fundamentos da fé: “... não faço mais do que pedir cada dia ao Senhor que tudo se desenvolva rapidamente, que se retorne aos puríssimos estudos da Bíblia e dos santos padres" ${ }^{\circ 7}$.

Em muitos de seus ensinamentos o Reformador afirma o conteúdo da fé tradicional com uma nova linguagem. Sua cristologia mostra o mesmo Cristo, Senhor, Deus e salvador, que a Igreja crê, conforme as Escrituras. Distancia-se da lógica racional abstrata da escolástica que reflete sobre a ontologia de Cristo numa perspectiva mais filosófica do que teológico-pastoral. A sua cristologia é experiencial, existencial, busca compreender o que Cristo é para nós no plano salvífico de Deus. É uma cristologia de conteúdo clássico, com linguagem nova ${ }^{68}$. O mesmo se observa na compreensão dos sacramentos, nos quais Lutero mantém a concepção agostiniana de sinal visível da graça invisível. Na eucaristia o Reformador se contrapóe a quem nega a "presença real" de Cristo, mas a explicita diferentemente da escolástica, rejeitando o conceito transubstatio por entendê-lo um excesso filosófico ${ }^{69}$.

Portanto, a Reforma náo pode ser lida na perspectiva de total rompimento ou prejuízo à Igreja do seu tempo. Em muitos aspectos ela é uma continuidade singular da catolicidade da fé. E dela vem também a possibilidade de correçôes na rota da Igreja, como um princípio crítico de determinadas seguranças estabelecidas. Assim é, por exemplo, na questáo da religiosidade popular, das estruturas eclesiásticas, da relação entre espiritualidade e vida.

A Reforma pode ser considerada, ainda, uma contribuição para que a Igreja possa melhor formular seus princípios de fé e seu desenvolvimento histórico, como uma nova compreensão de sacramentos, a relação entre leigos e hierarquia, o sacerdócio comum dos fiéis, a prioridade das Escrituras sobre a doutrina, a liturgia no vernáculo, entre outros. Embora tal renovação teológica tenha acontecido apenas no século XX, com o Vaticano II, existem significativas proximidades com o pensamento luterano. Não se trata de uma protestantização do catolicismo, mas da existência de um "benéfico influxo da theologia crucis sobre a estrutura do pensamento católico e o pathos que nela alimenta o poder das mediaçôes" ${ }^{\prime 0}$.

${ }^{67}$ Congar, Lutero: Lutero, “Carta a Trutfetter” (09/05/1518), 39.

${ }^{68}$ Lutero, "O debate sobre a sentença "O Verbo se fez carne", Jo 1,14 3, 240-243; idem, "Debate do reverendo padre senhor Dr. Martinho Lutero sobre a divindade e a humanidade de Cristo" 3, 275-299.

${ }^{69}$ Lutero, "Da santa ceia de Cristo" 4, 217-375.

${ }^{70}$ Montes, Reforma luterana y tradicion catolica, 12. 


\section{Partilhando a fé comum}

Assim, há elementos da fé católica nos luteranos e da fé luterana nos católicos. Estudos ecumênicos da Reforma mostram "as idéias da Igreja Católica romana aceitas pelas igrejas protestantes" ${ }^{71}$, como a dimensão universal dos atos da Igreja, superando tendências de afirmar apenas o valor da Igreja local ${ }^{72}$. Além disso, "a herança da Igreja antiga e da Igreja medieval é hoje muito apreciada pelas igrejas e a teologia protestante, e consideradas como uma parte indispensável de sua própria história”’3.

As igrejas protestantes valorizam mais hoje os ministérios ordenados na comunidade, reavaliando a sua relaçáo com o sacerdócio comum dos fiéis; dialogam com mais serenidade sobre o ministério petrino e dos bispos, em questôes como a sucessão apostólica e a importância do serviço de episkopé supra-regional. Estudos verificam, ainda, que

As igrejas protestantes tem adotado diferentes sugestôes das outras igrejas para a liturgia e a espiritualidade (bênçãos, vestes, velas para Páscoa e batismo. Elas novamente enfatizam a importância dos sacramentos como expressão da Palavra de Deus. ${ }^{74}$

E o que a tradição católica romana acolhe das igrejas oriundas da Reforma?

\section{Impulsos da Reforma luterana para reformas na Igreja Católica Romana}

As principais questóes doutrinais levantadas por Lutero e seus seguidores foram enfrentadas no Concílio de Trento (1545-1563), como a relação entre Escrituras e tradição, o cânon da Bíblia, o pecado original, a justificação, os sacramentos, as indulgências, a veneração aos santos, os ministérios eclesiásticos. Mas a perspectiva de Trento foi mais de resposta aos questionamentos dos reformadores e negaçáo das suas afirmaçôes sobre esses elementos da fé, do que como tentativa de rever a doutrina da Igreja ou mesmo de considerar a pertinência das críticas que, há tempos, a Igreja vinha recebendo.

Contudo, Trento não se limitou a responder aos reformadores. Mesmo sem propor mudanças na formulação doutrinal da fé, o tridentino transformou a vida concreta da Igreja e, nesse âmbito, foi um concílio reformista: exigiu a residência para os

\footnotetext{
${ }^{71}$ Grupo de Estudos Ecumênicos de Teólogos Protestantes e Católicos, “Réformation 1517-2017”, 81.

${ }^{72}$ Ibid., 80.

${ }^{73}$ Ibid., 81.

${ }^{74}$ Ibid., 81.
} 
clérigos, colocou fim no acúmulo de benefícios dos prelados, propôs a realização regular de sínodos diocesanos e provinciais, orientou que os bispos fizessem visitas pastorais regulares em suas dioceses, incentivou a formação do clero nos seminários, determinou que os padres pregassem todos os domingos e dias feriados, estabeleceu normas para a celebração do sacramento do matrimônio ${ }^{75}$. Tais reformas não satisfizeram as exigências protestantes, e nem era essa a finalidade de Trento. Mas elas foram significativas para a Igreja Católica e orientaram a vida de seus fiéis até o Concílio Vaticano II (1962-1965).

Foi com o Vaticano II que o catolicismo se viu reformado. A postura deste concílio não é de respostas às críticas dos protestantes, como se fossem frutos das circunstâncias, mas expressão da compreensão da identidade, natureza e missão da Igreja no século XX. O processo de aggiornamento do Vaticano II não se deu acentuando o que na fé católica diverge da fé protestante, mas pelo contrário, com uma especial preocupação em expor elementos da fé comum (UR 3. 15; $L G$ 8). Assim, o Vaticano II não foi um concílio marcado pelo clima da oposição, mas pelo da convergência; não se posicionou como uma "contra-reforma", mas numa perspectiva de "co-reforma"76.

O Concílio Vaticano II assume o conceito "reforma" como algo próprio da Igreja: Ecclesia est semper reformanda et purificanda ( $L G 8)$; Ecclesia in via peregrinans vocatur a Christo ad hanc perennem reformationem (UR 6). A razão de reformas/ mudanças na Igreja é a perseverança e atualização da sua vocação e fidelidade a Cristo. A verdade mais profunda do mistério eclesial não nos é facilmente acessível devido às contradiçôes que existem na Igreja enquanto organismo social e humano, muitas vezes marcado pelo pecado ( $L G 8$ ). É para que a sua verdade possa se manifestar de forma autêntica que a Igreja precisa de mudanças, conforme os tempos e os contextos das exigências do testemunho da fé, impedindo que esta seja engessada em formas anacrônicas de compreensão, linguagem e vivência. Não se tratam de mudanças ocasionais, mas de "reforma perene" (UU 6), expressão do modo mesmo de a Igreja ser enquanto peregrina neste mundo.

Com essa inspiração, muito do espírito da Reforma do século XVI se manifesta nas constituições, decretos e declaraçōes do Vaticano II. Ambas as igrejas, católica e luterana, podem dizer: "a Igreja precisa de reformas". A sintonia se verifica, por exemplo, na afirmação da prioridade das Escrituras sobre a tradição da Igreja (DV9), tendo como principal conseqüência o despertar bíblico na Igreja Católica romana, concentrando-se na proclamação do Evangelho; na afirmação do sacerdócio universal dos fiéis, com fundamento nas Escrituras, sobretudo em 1Pe 2,9 (LG 9-10,26,34; SC

\footnotetext{
75 Tüchle e Bouman, "Resposta e revide as novas forças e o Concílio de Trento”, 105-157.

${ }^{76}$ Feige, "Thèses catholiques pour la commémoration de la Réforme en 2017”, 5.
} 
14, 48; $A G$ 15; $A A 3)$; na eclesiologia entendida como "povo de Deus" ( $L G$, Cap. II); na liturgia eucarística no vernáculo; na integração entre ministros ordenados e leigos; na liturgia da Palavra como celebração independente realizada pelos leigos. Em notável sintonia com a Reforma, o acento cristológico é central em todos os documentos do Vaticano II, pois apenas Cristo é Lumen gentium $(L G 1)^{77}$. Constatar essas convergências é importante para a reconciliação das igrejas, mas não é tudo:

A contribuição delas para o fortalecimento dos esforços em busca da unidade dos cristãos católicos e evangélicos depende da forma como as igrejas desenvolvem, juntas, as convicçóes comuns constatadas. Para isso, urge abandonar o isolamento na formação dos fiéis, na organização das comunidades, na ação evangelizadora, na espiritualidade, para que cada vez mais os elementos comuns verificados possam, de fato, contribuir para que vivamos "Todos sob um mesmo Cristo" ${ }^{78}$

Com isso se expressa o significado ecumênico do conceito "reforma". Pois "a renovação da Igreja por meio do Espírito do Evangelho não é mais específico às igrejas da Reforma, longe disso. $\mathrm{O}$ apelo de Cristo à 'uma reforma perpétua' não é limitado pelas barreiras confessionais. As igrejas separadas são unidas na escuta do apelo de Cristo" 79 . A diferença central entre os dois processos de reforma é que aquela proposta por Lutero e seus seguidores propuseram mudanças substanciais nos atributos da Igreja. Apresenta uma nova compreensão da Igreja em sua própria interioridade e as mudanças externas ocorridas foram conseqüências ${ }^{80}$.

No Vaticano II, não houve alteraçóes na doutrina da Igreja, mas na sua formulação e na organização da Igreja, de modo que o novo proposto diz respeito, sobretudo às formas externas da organização, da prática, das estruturas da vida eclesial. Portando as igrejas não sintonizam em todas as propostas de reforma, e também há eclesiologias diferentes que dão o suporte teórico para as reformas na Igreja. As notas da unidade, santidade, catolicidade e apostolicidade não têm o mesmo significado teológico para todas as igrejas. Conseqüentemente, há "sintonias" no conceito de reforma, mas não "consenso", pois "uma compreensão interconfessional comum do conceito teológico cristão de Reforma exige, necessariamente, uma convergência sobre o conceito de Igreja" ${ }^{31}$.

\footnotetext{
${ }_{77}$ Grupo de Estudos Ecumênicos de Teólogos Protestantes e Católicos, “Réformation 1517-2017”, 79-80.

${ }^{78}$ Wolff, “Divisões na Igreja”, 398.

${ }^{79}$ Ibid., 71.

${ }^{80}$ Ibid.

${ }^{81}$ Ibid., 72.
} 


\section{No contexto dos 500 anos da Reforma de Lutero}

Às vésperas dos 500 anos da Reforma de Lutero, católicos romanos e luteranos são chamados a lançar um olhar conjunto sobre esses cinco séculos, verificar as implicaçóes para cada tradiçáo eclesial e também o que pode ser assumido conjuntamente. Esperase que as igrejas possam "recontar juntos a história da Reforma" ${ }^{2}$ à luz dos resultados do diálogo já realizado nos últimos 50 anos, e identificar o caminho que ainda resta a percorrer para uma plena unidade das duas tradiçóes eclesiais. O diálogo católicoluterano propóe:

Como membros de um corpo único, católicos e luteranos rememoram juntos os eventos da Reforma que levou ao fato de viverem posteriormente em comunidades divididas, mesmo se continuaram pertencendo ao mesmo corpo. Essa é uma possibilidade impossível e fonte de grande sofrimento. Porque pertencem ao mesmo corpo, católicos e luteranos lutam fazendo frente à divisão em busca da plena catolicidade da Igreja. Essa luta tem dois lados: o reconhecimento daquilo que é comum e que une, e o reconhecimento daquilo que divide. O primeiro é motivo de gratidão e alegria; o segundo é motivo de sofrimento e lamento. ${ }^{83}$

É uma proposta ousada e exigente, mas necessária no caminho da reconciliação cristã. O novo olhar comum para a Reforma não significa que os católicos estão, agora, reconhecendo tudo o que seus autores, sobretudo Lutero, propuseram; e nem que os luteranos se entendam católicos no sentido da tradição romana. O que se pretende é, de um lado, mostrar que também um cristão católico pode "elaborar perspectivas para recordar e apropriar-se da Reforma hoje ${ }^{{ }^{4}}$ em comunhão com os cristãos luteranos. E, de outro lado, compreender as características da catolicidade da fé luterana. Afinal, "A agenda da Reforma de Lutero representa um desafio teológico e espiritual tanto para católicos quanto para luteranos" ${ }^{35}$.

A comemoração da Reforma acontece em tom de esperança e em tom penitencial. Esperança, porque é uma ocasião para aprofundar a consciência de que católicos e luteranos mesmo divididos pertencem a um mesmo corpo. Essa consciência, fundamentada no batismo comum, impele às iniciativas de superação da divisão e à busca da plena catolicidade da Igreja. Vivendo em um novo contexto, náo se trata mais de um combate de uns contra os outros, mas de uma luta comum contra o que impede viver na unidade plena.

\footnotetext{
${ }^{82}$ Comissão Internacional Católica-Luterana, Do conflito à comunhão 35, 25.

${ }^{83}$ Ibid. 223 (84).

${ }^{84}$ Ibid. 3 (12).

${ }^{85}$ Ibid.
} 
Para isso é fundamental a consciência de que o cristianismo que cada uma vive, não lhe é exclusivo, uma vez que as duas igrejas partilham elementos fundamentais da fé cristá. A comemoração dos 500 anos da Reforma acontece também em tom de penitência, porque as igrejas reconhecem suas culpas na divisão dos cristãos: "é um momento para que luteranos e católicos experimentem a dor a respeito das falhas e desvios, culpa e pecado nas pessoas e eventos que são lembrados" ${ }^{\text {"6 }}$.

Espera-se que as igrejas estejam dispostas a não apenas "lembrar" os fatos da Reforma, mas "comemorar" e "celebrar", num espírito de alegria e agradecimento e, ao mesmo tempo, penitencial. Isso supóe um espírito ecumênico efetivo, sustentado nas convergências e nos consensos teológicos já alcançados pelo diálogo católicoluterano. Assim, essas tradições terão hoje uma leitura mais objetiva da história passada, identificando o que forma o contexto da Reforma do século XVI e suas conseqüências para o tempo presente, marcado pelo ecumenismo, a globalização e novas exigências da evangelização. Nesse horizonte é preciso uma convicta disposição para reinterpretar as tradiçóes teológicas, espirituais e práticas de evangelização, visando uma plena comunhão na fé.

\section{Conclusão}

No contexto da Reforma luterana, fatores externos à Igreja de entâo influenciaram de forma decisiva para a radicalização das posiçôes contrastantes, quando justamente o que se precisava era de diálogo e compreensão de ambas as partes. E o projeto da Reforma foi frustrado pela ruptura da comunháo. Conseqüentemente, os desdobramentos da Reforma acabaram por eliminar elementos essenciais para a Igreja relativos à tradição, ao episcopado, aos sacramentos, entre outros. Surge, assim, uma nova Igreja, que se sustenta também em uma nova confissáo de fé, mantendo elementos da tradição, mas também inovando em seu conteúdo.

Contudo, a Reforma de Lutero é um permanente convite a todos os cristãos: é preciso re-centrar a Igreja em Cristo e sua graça, superando as posturas de uma Igreja "auto-referenciada" ${ }^{87}$. A Reforma oferece aos cristáos de hoje um aprendizado no modo de ser cristão que implica em revisões necessárias nas doutrinas, estruturas e práticas da Igreja. Por um lado, todos os cristáos herdam da Reforma aquilo que lhes ajuda na fidelidade a Cristo e ao seu Evangelho. Por outro lado, assumem o compromisso de superar aquilo que na Reforma pode também dificultar a explicitação da verdade da fé cristá.

\footnotetext{
${ }^{86}$ Ibid. 227 (85).

${ }^{87}$ Francisco, Evangelii gaudium 8 (94-95).
} 
Para isso é fundamental "discutir a legitimidade das açóes históricas no olhar de Deus, como também a relação entre a ação de Deus e os acontecimentos históricos" ${ }^{88}$. A releitura ecumênica da Reforma ajuda a verificar se os pressupostos da separação entre os cristãos no passado são válidos para manter as divisóes no presente, sabendo que

O fato de compreender de modo diferente os acontecimentos complexos da história passada, como as diferenças que persistem nas questōes centrais da nossa fé, não deve dividir-nos para sempre. Nem mesmo as recordaçóes dos acontecimentos do passado deve limitar a liberdade dos esforços atuais para reparar os desastres provocados por tais acontecimentos. ${ }^{89}$

Urge superar a intransigência hermenêutica da fé que mantém o status quo das divisões, e acolher os resultados já alcançados pelos esforços de diálogo ecumênico. A busca da unidade cristã constitui a essência da vocação missionária da Igreja: "que sejam um... para que o mundo creia" (Jo 17,21), pois os que buscam a Deus hoje, e a humanidade como um todo, em nada são favorecidos pela divisão dos cristãos. É nesse espírito que deverá acontecer a celebração/comemoração dos 500 anos da Reforma de Lutero.

\section{Bibliografia}

Bayer, Oswald. A teologia de Martinho Lutero. São Leopoldo: Sinodal, 2007.

Brakemeier, Gottfried. "Doutrina da justificação. No limiar de um acordo ecumênico?”. In Doutrina da justificação por graça e fé, por Comissão Internacional Católica-Luterana,30-42. Porto Alegre: CEBI/Edipucrs, 1998.

Cereti, Giovanni. Per un'eclesiologia ecumenica. Bolonha: EDB, 1997.

Comissão Internacional Católica-Luterana. Do conflito à comunhão: comemoração conjunta católico-luterana da Reforma em 2017. São Leopoldo-Brasília: SinodalEdiçóes CNBB, 2015.

. Doutrina da justificação por graça e fé. Porto Alegre: CEBI/Edipucrs, 1998.

. "Il Vangelo e la Chiesa”. In Enchiridion Oecumenicum I, 5540558. Bolonha: EDB, 1994.

. "Martin Lutero, testimone di Gesù Cristo". In Enchiridion Oecumenicum I, 741-751. Bolonha: EDB, 1994.

${ }^{88}$ Grupo de Estudos Ecumênicos de Teólogos Protestantes e Católicos, "Réformation 1517-2017”, 54.

${ }^{89}$ João Paulo II, “Discurso à Federação das Igrejas Protestantes da Suíça (junho de 1984)". 
. "Tutti sotto uno stesso Cristo". In Enchiridion Oecumenicum I, 692-701, Bolonha: EDB, 1994.

. "Vie verso la comunione". In Enchiridion Oecumenicum I, 654-692, Bolonha: EDB 1994.

Comissão Católica-Luterana (EUA). "Giustificazione per fede". In Enchiridion Oecumenicum II, 1455-1558. Bolonha: EDB, 1988.

Congar, Yves. Lutero. La fede, la Riforma. Brescia: Morcelliana, 2004.

Federação Luterana Mundial e Pontifício Conselho para a Unidade dos Cristãos. Declaração conjunta sobre a doutrina da justificação por graça e fé. São Paulo: Paulinas, 1999.

. "Parecer". In Declaração conjunta sobre a doutrina da justificação por graça e fé, por Federação Luterana Mundial e Pontifício Conselho para a Unidade dos Cristãos. São Paulo: Paulinas, 1999.

Feige, Geharde. "Thèses catholiques pour la commémoration de la Réforme en 2017. Un défi salutaire”. Istina XLI, No. 1 (2016) 5-11.

Francisco. Evangelii gaudium. São Paulo: Paulus-Loyola, 2013.

Grupo de Estudos Ecumênicos de Teólogos Protestantes e Católicos. "Réformation 1517-2017: perspectives oecuméniques”. Istina XLI, No. 1 (2016): 51-88.

Iserloh, Erwin. "Come i cattolici giudicano Lutero oggi". Concilium 2 (1966): 16-27. João Paulo II. "Discurso à Federação das Igrejas Protestantes da Suíça (junho de 1984)”. Vatican, http://w2.vatican.va/content/john-paul-ii/it/speeches/1984/ june/documents/hf_jp-ii_spe_19840614_chiese-protestanti.html

Kasper, Walter. A Igreja Católica: essência, realidade, missão. São Leopoldo: Unisinos, 2012.

Lienhard, Marc. L'Évangile et l'Eglise chez Luther. Paris: Du Cerf, 1989. . "Luther notre maitre comum"? Istina LVIII, No. 3 (2013): 245-262.

Lorscheider, Aloísio. "Declaração conjunta da Federação Luterana Mundial e da Igreja Católica Romana sobre a doutrina da justificação". In Doutrina da justificação por graça e fé, por Comissão Nacional Católica-Luterana, 21-29. Porto Alegre: CEBI/Edipucrs, 1998.

Lortz, Joseph A. La Réforme de Luther. 2 vols. Paris: Du Cerf, 1970. . The Reformation in Germany. Londres: Darton, Longman e Todd, 1968. 
Lutero, Martinho. "A epístola do bem-aventurado apóstolo Paulo aos Romanos". In Obras selecionadas 8, 554-330. São Leopoldo-Porto Alegre: Sinodal-Concórdia, 2003.

. "À nobreza cristã da nação alemã, acerca da melhoria do estamento cristão". In Obras selecionadas 2, 277-340. São Leopoldo-Porto Alegre: Sinodal-Concórdia, 1989.

. "A respeito do Papado em Roma contra o celebérrimo romanista de Leipzig". In Obras selecionadas 2, 197-238. São Leopoldo-Porto Alegre: Sinodal-Concórdia, 1989.

. "Comentário da Epístola aos Gálatas". In Obras selecionadas 10, 22-557. São Leopoldo-Porto Alegre: Sinodal-Concórdia, 2003.

. "Da autoridade secular, até que ponto se lhe deve obediência". In Obras selecionadas 6, 79-114. São Leopoldo-Porto Alegre: Sinodal-Concórdia, 1996. . "Da santa ceia de Cristo”. In Obras selecionadas 4, 217-375. São LeopoldoPorto Alegre: Sinodal-Concórdia, 1993.

. "Debate do reverendo padre senhor Dr. Martinho Lutero sobre a divindade e a humanidade de Cristo". In Obras selecionadas 3, 275-299. Sáo LeopoldoPorto Alegre: Sinodal-Concórdia, 1992.

. "Debate sobre a teologia escolástica" (1517). In Obras selecionadas 1, 13-20. São Leopoldo-Porto Alegre: Sinodal-Concórdia, 1987.

. "Do cativeiro babilônico da Igreja" (1520). In Obras selecionadas 2, 341-424. São Leopoldo-Porto Alegre: Sinodal-Concórdia, 1989.

. "Dos concílios e da Igreja”. In Obras selecionadas 3, 300-432. São LeopoldoPorto Alegre: Sinodal-Concórdia, 1992.

. "Explicaçóes do debate sobre o valor das indulgências. Tese 89". In Obras selecionadas I, 55-190. São Leopoldo-Porto Alegre: Sinodal-Concórdia, 1992. . "O debate sobre a sentença 'O Verbo se fez carne', Jo 1,14". In Obras selecionadas 3, 240-243. São Leopoldo-Porto Alegre: : Sinodal-Concórdia, 1992.

. "Prédicas semanais sobre Mateus 5-7”. In Obras selecionadas 9, 21-282. São Leopoldo-Porto Alegre: Sinodal-Concórdia, 2005.

. "Resposta de Martinho Lutero ao livro de nosso exímio mestre mag. Ambrósio Catarino, acérrimo defensor de Silvestre Priérias com a explicação da visão 
de Daniel Cap. 8: sobre o antricristo". In Obras selecionadas 3, 11-95. São Leopoldo-Porto Alegre: Sinodal-Concórdia, 1992.

Martia, Giacomo. História da Igreja: de Lutero a nossos dias. I: O periodo da Reforma. São Paulo: Loyola, 2008.

Montes, Adolfo Gonzales. Reforma luterana y tradición católica. Salamanca: Universidad Pontificia de Salamanca, 1987.

Pesch, Otto Hermann. "La gracia como justificación y santificación del hombre." En Mysterium salutis VI/2, dirigido por J. Feiner y M. Löhrer, 790-878. Madrid: Cristiandad, 1975.

. "O estado atual do entendimento". Concilium 118 (1976-1978): 111-126.

Staufer, Richard. Le catholiciseme à la découverte de Luther (Le). Neuchâtel: Les Editiones Labor et Fides, 1966.

. "Mutamenti della interpretazione cattolica della figura di Lutero e loro limiti". RSCI 23 (1969): 361-383.

Tavard, George. A Igreja, comunidade de salvação: uma eclesiologia ecumênica. São Paulo: Paulus, 1997.

Tüchle, Germano e Charles A. Bouman. "Resposta e revide as novas forças e o Concílio de Trento". In Nova história da Igreja, por G. Tüchle III, 105-157. Rio de Janeiro: Vozes, 1971.

Weber, Max. A ética protestante e o espirito do capitalismo. São Paulo: Companhia das Letras, 2004.

Wicks, Jared. Lutero e il suo patrimonio spirituale. Assisi: Cittadella Editrice, 1984.

Wolff, Elias. A unidade da Igreja. Ensaio de eclesiologia ecumênica. São Paulo: Paulus, 2007.

. "Divisōes na Igreja: desafios para o ecumenismo hoje". In Theologica Xaveriana 65, No. 180 (2015): 381-407.

. "Reformas na Igreja: chegou a vez do catolicismo? Uma aproximação dos 50 anos do Vaticano II e os 500 anos da reforma luterana, no contexto do pontificado do papa Francisco". In Horizonte 12, No. 34 (2014): 534-567. 